\title{
Dreaming about the Dead in Premodern Korea
} (17th-19th Century)

Rêver des morts dans la Corée prémoderne (XVII -XIXe siècles)

조선후기 제문에 묘사된 망자에 관한 꿈

\section{Marion Eggert}

\section{OpenEdition}

\section{Journals}

Electronic version

URL: https://journals.openedition.org/extremeorient/1074

DOI: 10.4000/extremeorient. 1074

ISBN: 978-2-84292-990-9

ISSN: $2108-7105$

\section{Publisher}

Presses universitaires de Vincennes

\section{Printed version}

Date of publication: 1 December 2018

Number of pages: $43-72$

ISBN: 978-2-84292-988-6

ISSN: 0754-5010

\section{Electronic reference}

Marion Eggert, "Dreaming about the Dead in Premodern Korea (17th-19th Century)", Extrême-Orient Extrême-Occident [Online], 42 | 2018, Online since 01 December 2020, connection on 08 January 2022. URL: http://journals.openedition.org/extremeorient/1074 ; DOI: https://doi.org/10.4000/extremeorient. 1074 


\title{
Dreaming about the Dead in Premodern Korea (17th-19th Century)*
}

\author{
Marion Eggert
}

The cultural, philological and historical study of dreams, especially that of the last two or three decades, has directed its efforts ever more intensely towards historicizing the dream experience. While earlier comparative studies of dream cultures, often under the impression of psychoanalytical dream theory, had tended more towards seeking for universals in the power, appeal and functions of the dream, the tide turned towards understanding the dream as a highly culturally specific phenomenon, useful for unravelling the cultural grammars into which the diverging semantics of the dream feed, and from which they derive. ${ }^{1}$ The present essay is firmly rooted in the same endeavorunderstanding culture through the ways it deals with dreams. ${ }^{2}$ However, rather than aiming at deciphering specific cultural codes expressed through dream discourse, it takes a prior understanding of Sinic cultural codes related to dreams as background. Based on this, it makes use of narratives of dreamsmore specifically, the use of the dream motif in sacrificial texts for deceased beloved ones-as a pathway for describing the subjective experience of grief

* This work was supported by the Core University Program for Korean Studies through the Ministry of Education of the Republic of Korea and the Korean Studies Promotion Service of the Academy of Korean Studies (AKS 2014-OLU-2250001).

1. This change of trends can well be witnessed by comparing two influential collections of articles in the field: Caillois/von Grunebaum 1966; and Shulman/Stroumsa 1999. While both the title and Grunebaum's introductory essay to the earlier book bespeak the scrutiny of cultures/societies through the lens of their dealings with dreams, the majority of the contributions seem to be devoted to understanding the dream via its different cultural expressions, whereas the Shulman and Stroumsa enterprise was explicitly directed towards looking for the "differentiated, ... nonuniversal syntax of dreaming' in each of the cultures considered (p.12).

2. My own work on dream discourse in pre-modern China and Korea (esp. Eggert 1993, 1995, 2018) has consistently followed these lines. 
and mourning in Korean aristocratic culture of the Chosŏn dynasty, in the hope that this might function as a small contribution towards a better understanding of the construction of subjectivity among Confucian literati in Chosŏn Korea.

To be sure, the connection between dream culture and "the nature of the subject and its boundaries" has been pointed out and studied before, but usually by taking the culture-specific formation of subjectivity as explanans and the concomitant dream culture as explanandum. As Shulman and Stroumsa are formulating as part of the framework of their important edited volume on comparative oneirology:

A religious tradition for which the self is not real in the deepest ontological sense, or is ultimately to be dissolved, or is thoroughly interpenetrated with non-self elements, will undoubtedly produce a dream culture of a rather different nature. ${ }^{3}$

As can be judged from the larger context of these lines (which seem to have been written with East Asian traditions in mind), the assumptions behind them are not confined to the effects that religious anthropologies and value systems may have on literary representations of the dream, but encompass the claim that these anthropologies and values mold the formation of individual subjectivities in a way which directly affects dream experience (and therefore dream narration). In other words, the consensus on the existence of historically and regionally different dream cultures that has been built for the last decades typically includes, if not always explicitly, assumptions about equally different subjectivities underlying these dream cultures.

If, for the time being, we accept this close link between subjectivity and dream culture, it should be possible to turn the tables and ask what we can learn on the expression of subjectivity fostered by a Neo-Confucian worldview ${ }^{4}$ by looking at textual representations of dreams. This is the purpose of the following essay. One of the intentions behind this research is to put to test statements on Confucian subjectivity as found in role-ethical interpretations of Confucianism, such as the following lines by Henry Rosemont:

For the early Confucians there can be no me in isolation, to be considered abstractly: I am the totality of roles I live in relation to specific others. [...] [T] he relations in

3. Shulman/Stroumsa 1999: 6. The quote in the preceding sentence of my text is from the same place.

4. To be sure, Buddhist as well as Shamanist sub-currents informing Korean culture of Late Chosŏn times should not be played down. Yet, as argued below, the sources for the present study belong to the core of Neo-Confucian culture in Korea. 
which I stand to some people affect directly the relations in which I stand with others, to the extent that it would be misleading to say that I, play' or, perform' these roles; on the contrary, for Confucius, I am my roles. Taken collectively, they weave, for each of us, a unique pattern of personal identity, such that if some of my roles change, others will of necessity change also, literally making me a different person. ${ }^{5}$

If held against George Herbert Mead's famous distinction of I, Me and Self, the Self being the integration of the self-sense of the organism (I) and the person in its relation to and taking shape through the external forces of society $(\mathrm{Me})$, the ideal Confucian would be completely self-identified with his Me, knowing no I and therefore no Self. If this does not sound plausible to scholars of East Asian literature who regularly deal with expressions of much more tension between individual and society than accounted for by such a model of the Confucian self, it can be argued that Rosemont is speaking here of a normative idea attributed by him to Confucianism, not of the psychological reality of actual people. He and his fellow travelers would point out that the need for mediation between ethical norm and individual desires is clearly expressed in the Confucian canon, the paramount site for this mediation being the rites. ${ }^{6}$ Mindful of this argument, I investigate here expressions of emotion in a ritual context; this should be pertinent material for discussing the issue and testing the sustainability of this view of Confucian subjectivity.

I have thus chosen for this study texts composed for funeral and memorial rites (chemun, chin.jiwen) that speak of dreams about the dead. In contemporary Western thought, the theme of mourning itself has been closely related to the experience of self as autonomous individuality, so much so that we even find claims for a link between "the capacity to accept loss" and "the capacity for civic engagement." 7 While there is no need to subscribe to the idea in this probably overstated form and while it is certainly necessary to differentiate between the grieving process (which may have some or many universal

5. Rosemont 2016: $52 \mathrm{f}$.

6. This point has been emphasized by New Confucianists such as Tu Wei-ming and Sinologists such as Roger Ames alike. For a contribution that carries the emphasis on rites already in its title, see Ames 1988. The counterposition in this debate, which is of course much larger and more complex than I can do justice to here, is taken by scholars like Heiner Roetz who has consistently argued for a more differentiated view of Confucian ethics and personhood since his monograph Confucian Ethics of the Axial Age (Roetz 1993).

7. Levine 2011: 91. Again, these ideas can be traced back to psychoanalysis in the tradition of Siegmund Freud and Melanie Klein. 
features) and the cultural expressions of mourning and expectations towards the mourner, ${ }^{8}$ it may be uncontroversial to state that the cultural expressions of the mourning process must reflect, to a certain degree, the cultural frameworks within which a person's subjectivity is constituted. Texts of mourning that relate to dream experiences therefore bear the promise to provide us with some kind of documentation of subjectivity in its culturally framed expression.

Chemun appear as a rich source for the study of dream culture. They frequently make reference to dreams, even if they do not narrate specific dream experiences; the liminal character of both dream and death, the similar ontological questions they give rise to, and the bridge between the living and the dead that the dream seems able to provide are reasons enough. At the same time, dreams are not the subject matter of these ritual texts. When they relate dream experiences, or verbalize notions of the dream, they do so neither as part of a theoretical argument nor in order to avail themselves of the possibilities offered by the dream as a narrative device, but in the context of contemplating (and reinforcing) the relationship with a deceased person. They can therefore be expected to bring us somewhat closer to the dream (at least certain kinds of dreams) as lived experience in Chosŏn Korea and thus afford a better glimpse of the interiority and subjectivity of Confucian literati of the times.

\section{The Texts: Sample Selection and Genre Constraints}

The texts underlying this study are drawn from a large searchable fulltext database assembling more than a thousand Collected Works written by members of the educated elite, mostly of yangban ("aristocratic") status, in Literary Chinese.9 Sacrificial writings, chemun, constitute a searchable category of their own in this database. Within this category, I searched for full texts containing the characters for "dream" (mong) and for "see/appear" (kyŏn), as well as for the more formal "appear" (hyŏn) and "pay one's respect" (pae, used for dreams about parents) within a distance of eight characters. Another

8. This has been pointed out correctly by the anthropologist Douglas Hollan in Hollan 1995: 424.

9. [http://db.itkc.or.kr/]. Among the databases provided on this site, I have used only the one pertaining to Collected Works (munjip ch'onggan, first and second series). Note to non-specialists: All written philosophical discourse and most of high-brow literary production in pre-modern Korea was conducted in Literary Chinese; there is very little prose ego-documentation written in the vernacular before the late 19th/ early 20th century. Specimens in vernacular Korean that do exist often did not have a wide circulation, especially when written by women. 
expression, "make me dream of him/herself" ( $m o n g$ a) which curiously uses "to dream" (mong) as a causative verb, was also used as search term. Concerning the time period, the earliest result found was from an author who died in 1607, a clear indication of the fact, well described by Martina Deuchler, that the Confucian funerary rites prescribed from the early Chosŏn dynasty onwards ${ }^{10}$ were slow to take hold even among the elite. ${ }^{11}$

I confined the search to authors who had died before 1820, thus covering the better part of what is usually called the Later Chosŏn period. These roughly 200 years can be regarded as the period in Korean history during which NeoConfucianism was most firmly established within the elite. ${ }^{12}$ These searches generated a pool of altogether around 150 texts. Many of these texts speak of the dream in metaphorical ways, e.g. using the dream as a simile (for the brevity and uncertainty of life, or of the ritual situation); these texts were not taken into account. Of interest, but not of immediate relevance were the handful of texts speaking of dreams prior to the death of the person in question; usually these dreams were taken as an omen for the impending death. Of the 49 texts I could identify as actually concerning dreams about already deceased people, fourteen speak merely of the wish to meet the person in dreams. The remaining 35 texts ${ }^{13}$ that mention or, in the best case, narrate actual dreams featuring the addressee of the ritual form the main textual basis of this study and are listed chronologically in the reference list. ${ }^{14}$

10. For a brief outline of the state-led reformation of burial customs in the early years of the Chosŏn dynasty, see Hejtmanek 2014.

11. Deuchler 2015: esp. $192 \mathrm{ff}$.

12. While the 16th century saw the emergence of those intellectual figures who count as Korea's greatest Neo-Confucian philosophers, T'oegye Yi Hwang and Yulgok Yi I, these thinkers were so creative because they belonged to the intellectual avantgarde of the times, not the mainstream. Only from the 17th century onwards did NeoConfucianism fully shape the social and ritual life of the elite. Catholicism and the break-down of the Sinocentric political order eroded the authority of Neo-Confucian thought from the early to mid-19th century onwards.

13. Or, rather, cases, since in two instances, two texts by the same author were listed under the same number, since they concern the same dead person.

14. When quoting these sources I do not give page numbers since in the online edition, they are of no help in finding the text within the respective kworn of the munjip, and of little help for finding a passage within the text. 
Chemun or "orations," 15 literally "sacrificial writings," 16 were used for sacrificial rituals of different kinds, such as prayers for rain conducted by local magistrates. By far the majority of extant Korean chemun, however, were written for funerary rites conducted at different stages of burying and commemorating the dead, mostly at the occasions of interment and of the first and second anniversary of the death. For convenience's sake, we will call them here "funerary orations." Different from ch'ungmun or "invocations," which are short prayers written on wooden tablets and following rigid formulas, a chemun is a literary creation composed specifically for the occasion. Depending on the circumstances, it could be written in verse or in more or less ornate prose. Verse usually, prose sometimes makes use of the solemn four-syllable style evocative of Shijing poems. Parallel prose could also be employed, but occurs rarely in my sample. Generally, it can be observed that the closer and more informal the relationship between author and the deceased, the more informal the literary style of the piece.

Who exactly were the addressees of these texts? Chemun are always speech directed at the subject of the ceremony, be it a deceased person, a rain god or a venerated tree, and to be read aloud during the ceremony. The written texts of funerary orations were usually handed to the family of the deceased, who stored them as part of the public commemoration of their illustrious member, and when the persons' Collected Works were prepared, the number of chemun by friends and disciples that could be printed in the Appendix (purok) would be a marker of the person's social significance. Of course, they were also taken into the Collected Works of their authors, and we thus have a number of chemun that have been transmitted in two different munjip (and sometimes in slightly different versions). ${ }^{17}$ In spite of their literary character as direct speech addressed to the deceased, such chemun therefore can be considered to have been composed with vivid awareness of the social community of both author and addressed person as secondary audiences.

15. This is the translation offered by E. D. Edwards in her introduction to Chinese prose genres as catalogued by Yao Nai, Edwards 1948: 786.

16. This is also the translation used by de Groot in his explanations how jiwen replaced the lei ("eulogy") as "funerary offertories" from the Chinese early middle ages onward. See de Groot 1892: $1127 \mathrm{f}$.

17. Yi Homin's "Che Che Sŏae Yu sanggong mun," concerning Yu Sŏngnyong, is an illustrative example. The version contained in Yu Sŏngnyong's Sŏaejip contains an initial sentence where the author declares that he is passing by Yu's grave, setting up a ceremony and now announces the following. In Yi's own munjip, this line is left out and the text starts with the words directed to Yu Sŏngnyong. It may be assumed that the former text was given to the family immediately after the ceremony. 
Yet, sacrifices could be brought to the dead at any kind of occasion beyond those more formal instances of prescribed rites, and the character of chemun varies with these occasions. A husband might pour a libation to his wife who deceased decades earlier; a scholar may pass below the grave of an old acquaintance and use the occasion to commemorate him. In a number of instances, the text explicitly mentions that the author could not attend a certain formal rite; he had obviously conducted a private ceremony in its stead. In all these and many other cases, there is good reason to assume that the primary audience, the deceased person herself, was at the focus of the speaker's intentions. In these cases, the majority of which concern close kin, the paramount purpose of the text is not eulogizing the deceased or emphasizing one's own intimate connection with him for the sake of showing off or accruing social capital, but a-often discernably very urgent-attempt to communicate with the person in question. Chemun narrating dreams about the deceased often belong to this latter category: the rite and the dream form two parts of an intimate conversation. Indeed, at least two texts in my sample seem to have been composed in the context of a commemoration that was held because the deceased one had appeared to the speaker in a dream. This often very personal character of the funerary orations makes them a rich source for domestic life in the Chosŏn period. For our purposes, however, it means that we must expect expressions of grief to be rather exaggerated: It would be heartless and counter to the meaning of the ritual to emphasize the diminishing of grief or fading memories of the dead person with the passage of time. When we ask whether the dreams about the dead facilitated the coping with grief we must take this factor into account.

If the deceased person was the addressee of the sacrificial text, this seems to imply that the performers of the rite assumed that the soul of the deceased was present. This is a complicated question, and here is not the place to enter a full discussion on notions of the soul and afterlife in Chosŏn Korea. It emerges from past research ${ }^{18}$ as well as the present texts, however, that literati had different answers on this question at their disposal and were not always decided for one or the other: on the one hand, Confucian agnosticism which abstained from postulating a soul with the capacity of awareness and held that sacrifices should be conducted "as if" the soul of the commemorated person were present; on the other hand, traditions of folk religion, including popular Buddhism, which took the existence of such a soul after death for granted and

18. See Pettid 2014 and Hejtmanek 2014 on this question. For the transformation of these rites by Korean protestants into ch'udo yebae see Grayson 2007: 436-439; a discussion of the underlying concept of soul is missing there, however. 
ascribed to it great powers to influence the living. Given that the Confucian tradition also offered the notion of a (rather vegetative) paek soul remaining and decaying with the body in the grave and a "spiritual" hon soul slowly dissolving into higher spheres, the contradictions could be melted down to the question of how long the soul would linger close enough to partake in the offering, and to what degree it had remaining capacities of perception and communication. Uncertainty concerning this point is regularly expressed in chemun by questions like "does your soul have awareness or not?". ${ }^{19}$ That this tentativeness could call the rite itself into question is forcefully expressed in a text written by Yu Sŏngnyong (1542-1607) for his brother:

... This [the grave] can be a place for you to rest and to wander around in the morning and in the evening. If your soul has awareness, I think you will return here and saunter. If your soul has no awareness, my words are of no use. I will end them here. What can I do? ${ }^{20}$

\section{The Dreams: Causation}

Of similar opacity as the efficacy of sacrificial communication was the ontological status of dreams to Chosŏn literati. Again, tradition offered them a panoply of theories of the causation of dreams, covering the whole spectrum from physiological and psychological to spiritual and supernatural explanations. ${ }^{21}$ Thus, the same tensions between Confucian rationality befitting the scholar and more religious outlooks which he had learned in his youth from (female) family members and household servants can be witnessed with our chemun authors. It happens, therefore, that chemun featuring dreams raise questions about what made the dream happen:

19. 靈其知耶不知耶. Yi Sang (1620-1690), “Che Yi ch'amŭi mun.” Note that in this article, "soul' translates a range of different original terms, such as yŏng, hon, sinjŏng, chŏngsin, chŏnghon, chŏngryŏng. An attempt to differentiate between these terms would require a study of its own, and it is questionable whether it would be very successful.

20. 此兄朝焉夕焉息焉游焉之處。魂如有知。想歸來兮逍遙。如其不知。吾之言無 益。已矣已矣。柰何柰何. Yu Sŏngnyong, “Che paekhyŏng mun 祭伯兄文.”

21. For an overview over Sinic dream theories, see Eggert 1993: 80-110. See also Huntington 2017: 171-173 for a concise summary of dream theories most relevant for literati's understanding of their dreams about the dead. An overview over Korean dream culture and its literary expressions is provided by Yi Wŏryŏng 2011. 
I doubt whether you, brother, indeed came at that time and responded in my dream, or whether this was a result of my thinking of you? ${ }^{22}$

In my nightly dreams, I have often seen you; upon awaking, these were all just illusions. I myself have been [at the root of] this; how would you have made that happen ${ }^{23}$

The most ubiquitous view on this matter was, however, that the dream was an actual meeting of souls, and agency in this meeting was almost unilaterally ascribed to the soul of the dead person, since experience tells that dreams are not easily produced at will by living persons. The appearance of the dead person in the dream was therefore seen as a token of attention, affection or loving care bestowed on the living by the dead, just as a visit during lifetime would be. However, in the same way in which sincerity of the praying person was believed to induce a god or spirit to grant a wish, the attitude of the dreamersincere longing or grief - could be seen to play a role in bringing the dream about. Dream visions of the dead were thus a sign of a deep emotional and moral connection, as seen in this record concerning a close friend:

Dreams are not something that people can attain at their own will. That I in my dumbness was able to dream of you and mourn you in the dream shows how deeply your virtue has entered my heart. ${ }^{24}$

With junior family members, the matter was different: Since they had been expected to wait upon their elders in their lifetime, it could appear uncourteous to the latter if they failed to present themselves in dreams. Among the texts not taken into my sample, since they speak not about actual dreams but about unfulfilled wishes for dreams, are quite a few where grief and anger appear to mix in the plea to the dead to grant an appearance. Especially deceased daughters were sometimes berated as heartless by fathers who were not able to see them in their dreams:

22. 未知是時吾兄果來格而有感於余夢耶。郎余想之所因耶. Yi Samhwan (17291813), "Chae che ihyŏng Ch'ŏnggok-gong mun." Sang and in, thinking/longing and its consequences, are the key-words of a psychological dream theory formulated in medieval China (5th century), probably under the influence of Buddhist psychology.

23. 夜夢多見。覺來都幻。我自如此。豈君所使. Kwŏn Tŏksu (1672-1759), “Che mangsil yuin Kim-ssi mun."

24. 夢者非人所可任意而得者也 以某之頑能夢公而泣之 以公之贒入於心者深也. Chŏng Hyŏksin (1719-1793), "Che Yi Kych’o Puun mun.” 


\section{Marion Eggert}

You should enter our dreams at least once, so that we can fully express our grief. But I cannot see you in my dreams; when shall I be able to relieve my sorrow? In life you were so smart and nimble, attending to every detail in all affairs; in death you are so withdrawn, your love has become too weak. When I call you, you do not hear; when I speak to you, you do not answer. ${ }^{25}$

Conversely, the absence of dream visions could lead to, or deepen, feelings of guilt on the side of the mourner, who might feel rejected by the dead spirit. Thus, in a chemun for his elder sister with whom he had shared deep affections, Kwŏn Si (1604-1672) states that their emotional connection was so close that he used to always dream of her whenever she fell ill, "since because of our shared $k i$, our souls communicated in dream." That she has now been dead for ten days without his ever dreaming of her, he muses, must be because she bears a grudge against him for not seeking her out during her terminal illness. ${ }^{26}$ In yet other cases, the bereaved had no easy explanation for the lack of dream encounters. Cho Wihan's (1567-1649) profound search for possible answers to the conundrum illustrates well the expectations for dream communication and the perplexities surrounding it:

"On the day when your coffin was closed, I poured out my limitless feelings for you in a letter and put it into your burial case, expecting you to at least once come and answer me in a dream. But months and years have passed, and I have not been able to see your face. Is this because after death the hon and paek souls disperse, obliterated in darkness, and have no more awareness and knowledge? Is it that the dead and the living go parted ways, that a rift goes between the dark and the bright world, which makes it impossible for those to get in touch, even while wanting to meet? Or is it like in your lifetimes, when you were so afraid that I would fret about your illness that even when you fell sick, you would never speak of it to me; so that today you consider that if I in my grief would see your face in my dream, it would only increase my feelings of pain?" Or, he continues, is it because the parents spend their nights in sleepless grief, and "even though you want to enter our dreams, you cannot find a time for it?" 27

25. 宜一人夢。吐盡悲辭。夢猶未見。伸恨何時。生何聰慧。隨事委曲。死何冥 漠。恩情太薄。呼而不聞。語亦不答. Kang Paengnyŏn (1603-1681), “Mangnyŏ Nam Nangik Hun ch'ŏ chemun."

26. 是同氣魂夢亦相通也. Kwŏn Si, “Che Sim-ga cha mun.”

27. 汝之蓋棺之日。余書吾罔極之情。納諸殹中。冀汝之一者來報于我夢。而閱月 經年。㕿不得見汝之容顏。豈死者魂魄飄散。泯然冥然。都無知識而然耶。豈 死生異路。幽明有間。雖欲相接而不得相干耶。抑汝平日悶余其疾之憂。雖有 


\section{The Dreams: Contents}

The dream encounter being seen as sign of a link between living and dead that had to be activated by the dead spirit (facilitated and potentially, but not necessarily, instigated by the state of mind of the mourner) ${ }^{28}$ expectations for such dreams were naturally high - not only for their occurrence as such, but also for the contents and effects of the dream reunion. Yet, these expectations were rarely met even when dreams occurred; few records of dream events convey a sense of fulfillment or satisfaction. This is partly due to the chemun genre which, as mentioned above, naturally emphasizes lasting grief and was conceived of as a (though one-way) form of communication with the dead complementary to the dream: If the recorded dream(s) had fulfilled all communicative desires, the sacrificial text would have been largely obsolete. The dream records in the chemun can thus be sorted along the lines of in which way, and concerning which desires, they leave the hopes of the dreamer unfulfilled. I will call the resulting categories tentatively reunion dreams, stateof-the-dead dreams, message dreams, and leave-taking dreams.

\section{Reunion dreams}

The first and most obvious wish of the living concerning the dead would be reunion. Quite a few texts in my sample tell little beyond the occurrence of dreams, usually mentioning that the dead beloved one appeared like in life-time, ${ }^{29}$ and sometimes adding that they talked and laughed together as if nothing had happened. In all cases this brief suspension of loss during the dream is juxtaposed with the onset of (renewed or heightened) grief after awakening: "Sometimes I see you in my dreams; but this is again not real.

病時。常諱而不言。今亦念余哀疚之中。夢見汝面目。則尤增傷痛之懷也。爲 此而不見於夢耶。余不忍見汝平日寝處之所及几筤之設。殯之翌日。出避村 家。斗屋如漆。煙塞書昏。獨與汝母聚首號擗。更啼迭哭。達曙竟㫡。少無 交睫之時。則雖欲入夢而不得乘其彷彿之頃耶. Cho Wihan (1567-1649), “Che mangja Ǔi mun."

28. Of course, this view of the dream was not necessarily shared by all literati. It must be remembered that we deal here with a subset of authors who chose to write about dreams in their chemun - a small minority after all. The consulted database records a grand total of exactly 52.654 chemun, of which only 2.636 texts carry the character mong at all.

29. See e.g. the chemun by Kim Hongyu, Kang Paengnyŏn (9), Yi Sisŏn, Ch'oe Sŏkchŏng, Song Sanggi (both), and Yi Ŭihyŏn. 
On my pillow and mat, I can just cry by myself." ${ }^{30}$ Or, in more philosophical terms: "In my dreams, I have repeatedly seen your figure, completely as in real life, and did not know about my sorrow. How disparate dream and waking life are!" 31 This holds even when the "real life" situation evoked in the dream is not positive, like in the case of the husband always dreaming of his deceased wife in her state of grave illness; and yet, the text implies, the sorrow about her being ill that he feels is nothing to groping for her and not finding her after awakening. ${ }^{32}$

\section{State-of-the-dead dreams}

A second kind of dream narration, also normally quite brief, concerns the desire to know how the dead person is feeling him- or herself, which can be correlated to an urge to re-establish the relationship or to reassure oneself that the spirit of the dead harbors no ill feelings. In the respective dream narrations, the dream apparition is usually described as communicating his or her emotional state not through words but through countenance and gestures, looking happy and content, sad, or compassionate. ${ }^{33}$ While these dreams are always welcome, they put no end to the worries and questions of the bereaved. Thus, the relaxed dream countenance of his deceased son motivates Cho T'aeŏk (1675-1728) to ask the latter whether he was not just trying to protect his father's feelings and therefore would hide his own sorrow. Song Siyŏl (1607-1689), sacrificing to his daughter-in-law to whom he felt obviously very close, inquires about the reasons of her sad appearance and tries to comfort her soul. I will quote him at length in order also to illustrate the intimate tone of conversation that can be found in some sacrificial writings:

You appeared a few times in my dreams, and always you looked bitterly mournful. What is it that causes you the most sorrow? Are you, I wonder, worried that your small children now have no one to take loving care of them? This is definitely not so. Both Suhŭi and Sŏngnin are with myself and your mother-in-law, and we look after

30. 有時夢見 亦復非眞 枕席之上 只自涕泣而已. Song Sanggi (1657-1723), “Che manga mun."

31. 夢見汝形至于再 宛如平生 不知爲悲 夢與覺忡馳之何若是邪. Yi Sisŏn (16251715), “Che chongja chwarang Sŏn mun."

32. Kim Sangjŏng, "Che mangsil mun."

33. See the chemun by Cho T'aeŏk, Song Siyŏl (11), and Kim Yun'an, respectively. 
them more diligently than ever before. The way Chikchŏng ${ }^{34}$ raises Yonggyŏng is no different from how you would do it yourself. Sŏngnin by now knows how to formally pay respects, and can write and recite texts. I hear that Yonggyŏng laughs a lot and is about to learn to speak. Only when Sŏngnin asks where his mother is, we say that she is in the house in the capital. People all get stuffed-up noses when they hear this; you can infer how I myself am feeling when this happens. ${ }^{35}$

The most moving and most telling example of such dreams of state-of-thedead is Ko Yŏnghu's sacrificial letter to his wife, which has a grim background. Ko Yonghu, born 1577, had made a smooth career up to 1631 when he was implicated in a political affair and sent to exile in Yŏngdŏk (today's North Kyŏngsang province) in the second month. This punishment seems not to have sufficed to his adversaries, who put his past behavior under scrutiny and found that he had embezzled ginseng (serving as currency) during his mission to China the preceding year. He was thus in the seventh month dragged back to Seoul and jailed. At this moment of imminent danger for Ko's life, his wife killed herself, thus creating a situation in which king and court had to show clemency: Ko was released and exiled to Chinju (today's South Kyŏngsang province). It was there that he brought a sacrifice to his wife on the day he knew her burial was scheduled. His sacrificial text, in which he credits her for having saved his life, is naturally full of feelings of guilt and remorse. All the more important for him must have been her apparitions in his dreams:

Alas! From first [after your death] up to now I have frequently dreamt of you. Your speech and breath were always peaceful, your words calm and detailed. You gave not the least impression of being sad or bitter. This must mean that your heart is at peace with your death and feels no more fright, and that in a happy reunion of souls, you are enjoying yourself at the threshold of the world of eternal light. ${ }^{36}$ But what about me who remains in the world of the living? Alas! Even if I go up high on the

34. Millet hall —in all likelihood a toponym standing in for a female person.

35. 一二夢見 每有哀苦慘悽之色 汝之所悲恨者 最在何許 得無諸兒幼稚 無復撫 視者耶 此則豈其然乎 秀喜, 聖麟 吾與孃也 看護之勤 有加於前 稷庭之鞠字 龍庚 豈 異於汝乎 麟也于今能知拜揖 亦能作字誦文 又聞庚也孩笑欲語 惟麟 也人問汝母安在 則師曰在于京宅 人無不釀涕 鴙余之懷將何如也. Song Siyŏl, "Che chabu Yi-ssi mun."

36. This is as close as I can get in translating changgyŏng myŏnghwi which derives from a Tang poem, "Dancing Song (Tage)" by Lan Caihe. Of course, the phrasing should not be understood in a Christian sense. 


\title{
Marion Eggert
}

mountain top, or go the rim of the blue ocean, my wailing and weeping will find no end, and will never suffice to console your heart and set limits to my sorrow. ${ }^{37}$

As consoling as dreaming up the forgiveness of his wife may have been, the dreams must be supplemented by the rite, since they are only the beginning of a communication by which Ko hopes to attain absolution by his wife. ${ }^{38}$ Therefore, in a final passage that will be of interest for students of female literary life in the Chosŏn as well, the writer seems to attempt to reassure himself both of the achievement of communication through the sacrificial oration, and of actually attaining the forgiveness which the dreams promised:

\begin{abstract}
Alas! In lifetime, you were exceptionally intelligent. The texts I read aloud you could repeat after just listening once, without any hesitation or obstruction. So you will certainly understand the chemun I am writing and sending you here. Will you be able to believe in my sincerity ${ }^{39}$
\end{abstract}

\section{Message dreams}

Such desire as can be felt here for communication that affects the life of the bereaved themselves, for messages from rather than knowledge about the deceased, is often the background for the third kind of dream narration: records of interaction and conversation between living and dead in the dream, beyond the formulaic "talking and laughing." Naturally, the most detailed and lively dream stories in my sample all belong to this category, but even in brief or rather fragmentary narrations ${ }^{40}$ we can see the principle at work. The oldest text in the sample very succinctly illustrates the difference between reunion dreams and message dreams, even though the message remains missing:

Since you have died, brother, I have frequently seen you in dreams. Sometimes you joined the other siblings in keeping company with our parents, completely like in

37. 鳴呼。自初至今。吾頻夢子。子辭氣和平。言語安詳。了無愁怨之狀。是子 之心瞑目泉壤。更無所恫。團圓魂魄。必自樂於長景明暉之際。而奈此在世人 何哉。鳴呼。雖登高山之䀧。臨滄海之 涯。啼號涕泣。無有已時。曾不足以 慰子心而塞吾之悲矣. Ko Yonghu (1577-1652), “Che mangsil sukpuin Ki-ssi mun.”

38. Earlier in his text, he pleads guilty for having brought both of them into this horrible situation by his misbehavior.

39. 鳴呼。子之生也。聰明脫凡。吾所讀書。聞之輙誦。略無滯雍。則今也寫送之 祭文。的應解其國。而其能以諒吾之忱乎. Ko Yonghu, $i d$.

40. As in the chemun by Yi Chŏnghyŏng, Yi Homin, and Song Siyŏl (10). 
your lifetime. At other times, I knew that you were already dead, and I asked you whether there was something you wanted to tell, but you did not answer. ${ }^{41}$

The attempt to solicit a message from the dead is specifically tied to his manifestation as a dead person in the dream. We do not know why Yi Chŏnghyŏng asked his brother to speak, but from other sources, two main motives emerge: to acquire the knowledge necessary for putting the dead to real rest; and to obtain their advice and protection. The former may concern emotional issues, such as in the case of a wife who comes into her husbands dream with a sad expression, telling him that she has something to say about which she could not speak while alive (she fails to tell him in the dream, but he can gather the story from his sister).$^{42}$ In other cases, it concerns practical issues, such as finding the right burial place. The following dream is told by Yi Ch'ŏlbo about his uncle:

One day in the eighth month, I saw you galloping towards me on horseback. You came from the north towards the south; I went to meet you at the roadside. You dismounted your horse, shook hands with me, and we sobbed. After a long time, you said: Hadn't it better be...? It seemed as if you were talking about the grave situation. But before finishing your sentence, you suddenly mounted your horse and galloped back. After awaking, I was sorrowful as before and could not sleep until dawn. While you were alive, it never happened that you did not speak to the end with me; how does it come about that you wanted to speak but did not speak, only increasing my grief? Is it that your soul is adrift, suddenly coming and suddenly going, not as composed as during your time on earth? Or is my sincerity lacking, insufficient to move the intentions of your spirit so that it would bare itself to me? ${ }^{43}$

In another case where likewise the burial site is at stake, the (living) younger brother earnestly berates his elder brother for leaving him alone with the difficult decision instead of coming into his dreams and pointing out the right place. ${ }^{44}$ Since the burial sites were believed to exert great influence on the

41. 自兄之亡。頻夢見中。或同兄妹。俱在親側。宛如平生。或知其已死。問兄 以有所言。兄不應. Yi Chŏnghyŏng (1549-1607), “Che chunghyŏng mun."

42. Yi Haejo, (1660-1711), "Che mangsil sosang mun."

43. 八月之日。夢見 叔父騎馬而馳。自北而南。小子迎拜於道。叔父下馬而握手 鳴咽良久曰寧有是耶。盖其意似指山事而語未卒。輙騎馬還馳。覺而依然。悲 耿達曙。叔父平日於小子。未嘗有說不盡者。顧何爲欲言而不言。徒增小子之 慽耶。豈精魂悠蕩。忽來而忽往。不比人世之從容耶。抑小子誠淺。不足以感 激神意而展盡其衣曲耶. Yi Ch“ŏlbo (1691-1770), “Che kyebu mun.”

44. Yu Semyŏng (1636-1690), "Che sahyŏng Maedang-gong mun." 
fate of the living relations of the dead, these matters were of utmost relevance for family fortunes, and this long chemun documents not only grief at the brother's passing but the survivor's anger at having been deserted by his elder brother, seemingly aggravated by the fact that the dead brother does appear in the dreams of the living sibling, but never mentions the important issues.

Even when the dreamer succeeds in obtaining a message from the dead, dream communication is conceived as unreliable. Another young man waiting for instructions from his deceased elder brother was Yu Chin (1582-1635), son of Yu Sŏngnyong. He wished to know from his brother Yu Tan (1580-1612), who had died five months earlier without an heir, his opinions about the right decision on his ritual succession:

What you told me in a dream when I lay ill on Wit-Pamsŏm 45-I wonder whether this is really your wish? If this is really what you wish, why don't you appear to me in another dream, or appear to my sister-in-law, so that we can be at ease with the decision? ${ }^{46}$

Yu Chin hesitated whether he should offer his older or his younger own son to his brother as ritual heir, since there were good arguments against both choices. Still, he may have felt that the wish expressed by his brother in the dream was the less appropriate choice. His uncertainty was probably aggravated by the fact that he felt guilty for his brother's death: Yu Tan had contracted a letal fever while accompanying his younger brother to Seoul. All the more he must have felt obliged to offer his brother the perfect ritual successor.

Remorse and guilty feelings are the background of yet another dream communication that does not fully convince the recipient. Song Siyŏl, in dreaming of his deceased friend and mentor Yi Huwŏn (1598-1660) whom he had unwittingly compromised by his political behavior, ${ }^{47}$ suffered the latter's criticism:

45. An island in the Han river in Seoul which has been destroyed in 1967 in the wake of expanding Yoŭido.

46. 向日余之病臥於上駕山也。兄之夢告於余者。不知果兄之意邪。兄若果有是 意。則何不再夢於余。或夢於嫂氏。使之釋然以定也. Yu Chin (1582-1635), "Che chunghyŏng sema-gong mun."

47. Yi Huwŏn had been behind Song's promotion to high office in 1657, so that Song's subsequent behavior would be in part attributed to him. The chemun is full of allusions to Song's having implicated Yi, but the details remain unclear. Yi Huwŏn died a natural death. 
In the dream that I had the other day, you heavily berated me, and you again spoke about how in the winter of last year, your words had been divulged. Awaking, I sat up, with bloody sweat on my cheeks. Alas! Although I am ill-mannered, how could I doubt you, that you warn me like this? ${ }^{48}$

Added to the chiding was a warning or advice, it seems, and in the ensuing passage of the text Song discusses arguments why he should probably not heed it. It may have been due to his doubts about the reliability of the dream communication that in one version of the text, he inserted an additional comment after "alas": "Have you really entered my dream, or has my endless sorrow induced our spirits to meet and create the dream?" ${ }^{49}$ Psychological or naturalistic dream theories had been brought up in early Confucianism as a means to contain autocracy by a ruler who might use dreams as pretexts for solitary decisions. ${ }^{50}$ Here, they can again be witnessed to protect from unwarranted authority; at the same time, recourse to these theories was not even necessary to throw doubt on the reliability of messages obtained in one's own dream. As the chemun richly testify, even when the tangibility of the deceased soul was firmly believed, doubt was never far away in interaction with them, since neither their motives nor their actual powers of harming or protecting the living could be fully known. Whatever else it was, the dead soul manifesting itself was an interpretandum.

\section{Parting dreams}

A final category of dreams is set apart by its common theme of parting. Leave-taking of the dying or deceased soul or the parting of the ways between the living and the dead is either enacted in the dreams, or is part of the dreamer's interpretation of his dream experience. Thus, a dream occuring in the night of the respective person's death,,$^{51}$ or briefly before the announcement of the death arrives ${ }^{52}$ is interpreted as a fare-well message of the deceased and a token of

48. 噫疇昔之夢。兄見余刺刺。復及前冬語洩之事。覺來起坐。清血交頤。嗚呼。 余雖無狀。豈敢疑兄。而如是丁寧耶. Song Siyŏl (1607-1689), “Che Ujae Yi-gong mun.”

49. 兄眞入我夢也耶抑余悲慕無涯故精神相感而然耶. See the annotation in the electronic version. It remains unspecific about where this alternative version can be found.

50. Cf. Wagner 1988.

51. Yi Sang (1620-1690), "Che Yi ch'amŭi mun."

52. Kang Paengnyŏn (1603-1681), "Chaja Yi jinsa Sŏngik chemun.” 


\section{Marion Eggert}

the depth of mutual sympathy. In some such cases, the leave-taking dream also enacts the parting:

In my dream, I saw you on the mountain-side beyond a river, waving good-bye, as if you were leaving for a long journey. On this day, I departed for Seoul in order to inquire about your illness, and on the way, I intercepted the announcement of your death. ${ }^{53}$

When the subject of the dream is already known to have died, such leavetaking dreams can be especially vivid. Yu Chin, whom we have witnessed entreating his deceased brother for concrete advice, earlier in the text narrates the following dream full of Taoistic imagery:

Alas, how painful! On the day after your death, I saw in my dream you and our eldest brother, both clad in black robes and wearing black shoes, adorned with gaze hats and with plated belts [showing the official rank]. A dozen musicians surrounded you playing music. With a sound like striking metal or stone, you rose on the clouds and rode away on the wind. I gazed towards you but could not reach you; and stood dazed and weeping. You turned to look at me and said: Sooner or later we will see each other again; do not take this to heart. ${ }^{54}$

Such dreams explicitly thematizing the leave-taking of the dying or dead soul are usually recorded in close temporal proximity to the person's death. With the passage of time, we find in their stead dream narratives not so much about bidding farewell than rather about the diminishing of the beloved soulstatements of a process of slow dissolution of the social bond expressed in terms of the dreams dreamt or not dreamt. Thus, a father speaks to his daughter who has been dead for a year:

Since you have died, there was not one day when you have not been on my mind, kept alive in my mind, and often you have issued forth during my nightly sleep. But now after one year I see you only once in a while in my dreams, and the dreams are hazy. Does this mean that your soul is dispersing, so that the affects remain without

53. 夢見君依山隔水。擧手以辭。若有遠行者。是日將走洛問疾。而道承君訃. Nam Yuyong (1698-1773), “Che woehyŏng Yi-gun Sejin mun."

54. 鳴呼痛哉。兄逝之翌日。夢見兄與伯兄。皆被黑袍曳黑履。紗帽角帶。樂工十 餘人。先後作樂。聲戛金石。乘雲御風而去。余瞻望不及。竚立以泣。兄顧謂 余曰早晚當相見。勿以爲念也. Yu Chin (1582-1635), “Che chunghyŏng sema-gong mun.” 
response? If my love for you, my pity for you, my grieving and cherishing you have already changed over the months and years, who will after this know at all that the world has seen a human being like you? ${ }^{55}$

Conversely, another father of a deceased daughter, who describes the same phenomenon, wonders whether her feelings have diminished.56 Taking both possibilities into account, a father commemorating his son at his second anniversary of death notes that his dreams of him have ceased during the second year, and asks: "Did I really forget you? Or did you leave me for good? Have you have finally become another kind of being, so that your soul-ki cannot get into contact with me anymore?" 57

In terms of the desire they leave unfulfilled, the parting dreams (including the series of dreams that are interpreted as indicators of growing distance) are the mirror image of the reunion dreams. Both bespeak the desire of communion with the beloved dead, but while the reunion dreams are uniformly told in the context of inconsolable grief, the parting dreams contain seeds of consolation or are told in the context of overcoming grief. Dreams enacting the leavetaking carry the promise of an unbroken bond of love and commitment beyond the life-death-barrier, while accounting for the slow fading of dreams about the dead affords the bereaved an opportunity to contemplate their own coming to terms with the loss. This link, visible in text by Sin Tae'u quoted above, is illustrated in a dream narration that does not strictly speak of a process of lessening dreams and yet seems to belong to the same category for its emphasis on the elusiveness of the dream experience. Ch'ae P'aengyun writes in a chemun for a friend:

Since you have departed from the world, I have often seen you in dreams. Sometimes you were nearby and yet seemed remote; sometimes I looked for you and could not see you; sometimes we were bantering like in olden days; and then again you seemed to speak about affairs after death, unfathomable and mysterious, things that can not be verified. But to be so enmeshed in one's grief and longing that one wants to meet in dreams in order to be able to see the beloved face: this is grief. If I take

55. 自汝之亡。無汝一日不在吾心。存於心者。多宵棩發之。而周歲僅一再見汝於 夢。夢又不了。殆汝神精銷散。有感無所應然與。以吾愛汝憐汝哀汝惜汝之 心。向且月殊而歲不同。過此往誰復知世有若人. Sin Taeu (1735-1809), “Mangyŏ sosang chemun."

56. Kim Suhang (金壽恒1629-1689), “Mangnyŏ taesang chŏn iil chemun.”

57. 余果忘汝歟。汝眞㶳余歟。汝遂判作異物。魂氣不與余交涉歟. Yi Mansu (1752-1820), "Mangja Wŏnu taegi chemun." 
life as a dream, then I can end my days just dreaming; this will be even better than the dozen years that I spent with you in scholarship. If I dream in order to discard the world, I will meet you in a haze and be separated from you in confusion; this only increases the sorrow. ${ }^{58}$

Consolation lies not in the dreams but in the attitude found through them. The religious overtones of this text at large are not fortuitous: The leave-taking dreams direct the vision of the mourner to the Beyond-beyond mortal life, and thence beyond grief.

\section{Mourning Process and Late Chosŏn Subjectivities}

The categories of the chemun dream narrations distinguished above have been derived at by sorting the text according to thematic clusters, which then proved to often correlate with narrative procedures. Especially the two kinds of leave-taking dreams with their temporal sequence suggest that these different kinds of dreams might also correlate in some way to the mourning process, i.e. to the process of coping with and overcoming grief. In order to find evidence for this impression, I have examined the time that typically elapsed between the event of death and the occurrence of the dream. Of course, the texts often do not state this explicitly. Inference had to be made in these cases from the time span between event of death and conduction of ritual, but the latter was also not always clearly given in the texts. Yet, a pattern emerged:

- Reunion dreams are usually recorded as having occurred close to the time of death; they are most regularly mentioned in chemun composed for the funeral.

- State-of-the-dead dreams usually appear as having occurred somewhat later, but within the first year after bereavement. None of them are dated, and they are sometimes said to have occurred repeatedly. The respective rituals were conducted between one week and approximately eight months after the death event.

- The dating of message dreams was the most unclear, but they are found in ritual texts that span the time from the funeral until two years after death, and with one

58. 自公之逝。屢見于夢。或近而若遠。或覔而無所見。或諧謔類常。而復類言身 後事者。寥闊誕幻。不可以徵。然彼有沉痛戀想。煩紆甚者。願寧接于夢㻗。 以見顔色。斯戚已。世而猶夢也。得盡余之齒。以夢而不已。則其視十數年從 游於文墨者。殆有愈焉。夢而非世也。怳然而合。惚然而散。秪益悲矣. Ch'ae P'aengyun (1669-1731), “Che Och’on Hong Ǔnggyo Ton mun.” 
exception (a message by his wife conferred to Ko Yonghu in a half-dream at the time of her death) there is no indication that they occurred soon after the death.

- Parting dreams, as noted above, are typically recorded as occurring in close proximity to the death event for the leave-taking variety, while the diminishing soul variety is usually found in chemun composed one or two years after the bereavement.

The question how this pattern of changing dreams over time correlates to the expression of grief or descriptions of the "work of mourning" in the respective chemun at large must await future research. However, based on the observations presented above, striking similarities can already be noticed between these Late Chosŏn narrations and the dreams about the dead by late 20th century American university students which have been the object of a much-quoted study by psychologist Deirdre Barrett. ${ }^{59}$ She defined four dream categories, termed-in the sequence of their temporal occurrence-"back to life," "advice," "leavetaking" and "state of death" dreams. The first three of these categories are easily identified with our first, third and fourth categories. "State of death" dreams are defined as dreams in which "the dream character describes the state of death" to the dreamer, i.e. reveals "what it was like to be dead." However, of the two dream narratives given as example, one starts with the question "how are you" asked to the "dream character," the student's deceased grandmother, while the other speaks of the deceased person "describing the wonderful place where he was." ${ }^{60}$ In other words, dream narratives subsumed by Barrett under this category may be characterized not only by curiosity about the afterlife, but also by an interest in the deceased person's emotional state similar to our stateof-the-dead dreams. We can conclude, then, that dream themes are remarkably similar, while the differences and similarities in temporal sequence would warrant a closer discussion which again has to be done at another occasion. ${ }^{61}$

Another very influential classification of dreams in a psychological study, Kuiken and Sikora's work on "impactful dreams," again affords a "recognition effect." Among impactful dreams, those involving "persons who, in the

59. Barrett 1991-92.

60. Barrett 1991-92: 104-5.

61. The observed differences may partly hinge on the different ways in which the materials were obtained, the dream stories underlying Barrett's study having been solicited by the psychologist herself. Also, Barrett does not discuss how reliable the dating of the dreams by her informants was. Some of the differences may be explained by different religious concepts, e.g. ascription of agency to the soul of a dying person which may make it more likely for Late Chosŏn literati to experience (which is, to interpret) a certain dream as a leave-taking. 


\section{Marion Eggert}

dreamer's waking life, were actually deceased' are found to often belong to the category of "existential dreams," which are marked by the emotion of sadness, the motive/concern of separation, a shift in emotion during the dream, and intense affects in the dream's final moment. ${ }^{62}$ Our sample contains very few specimens of dreams that can usefully be checked against such categories won in the sleep laboratory, since the chemun dream stories, even though in all likelihood relating actual dreams, ${ }^{63}$ rarely appear to be narrated with attention to details, which would mean retaining the latter in their dream-likeness rather than obliterating them for the sake of narrative consistency. However, the two dream narrations that come closest to such true-to-life dream stories contain all the elements of the "existential dream." The first is found in a chemun written by a father for his son:

Since you entered the earth, I have seen you often in my dreams, but always in a vague and fleeting manner, an unclear likeness; never has a dream been as crystal clear as this night's one. Your appearance and your speech were no different from what they had been in the past, although I cannot remember the words we exchanged. But it seems that you pointed to a mountain waterfall like the one at Ongnyu-dong and said: This is a good place to stay. The room we were sitting in also seemed like the garden house in Yangsan, but it was not clear. Min Sawŏn ${ }^{64}$ and a few others whom I did not know sat with you, but they didn't say anything. I was neither overjoyed nor sad, just like in the olden days when you were with me, for I did not know about your death. Only when you were about to leave, I seemed to have suddenly become aware of it: I held you and lamented, saying: After this parting, shall we ever meet again? Letting out a cry, I awoke, and wept bitterly. My mind was utterly perplexed, and I could not compose myself. The hour-glass had run out, and the cocks crowed profusely. ${ }^{65}$

62. Kuiken/Sikora 1993: 433-437.

63. Since the chemun were conceived of as communication with the person who appeared in the dream, it is unlikely that the dreams were as a rule just a literary device.

64. This is probably Min Usu (1694-1756), styled Sawŏn. Given his date of birth, he may well have been friends with Nam Han'gi's son(s).

65. 自汝入地之後。至今日。夢中見汝亦多。而怳怳惚惚。依俙不明。未有若今夜 之了了。顔貌言辭。無異平昔。而酬酢之言。都不能記。猶是指山上瀑布。如 玉流洞者曰。此處便佳云云。所坐之室。亦似楊山庄舍。而猶不分明。閔君士 元。與客不相識者。同汝一席。而亦無所言。只是余無喜無悲。不知存亡。如 汝平日侍傍時。臨去之際。余若有悟。相持慟哭曰。此別之後。更當相見否。 仍放聲而覺。飲泣不已。神思迷惘。不能自定。時漏已盡。而雞亂鳴矣. Nam Han'gi (1675-1748), "Che manga mun." 
The second, shorter, but also very vivid dream was recorded in a chemun for a close friend:

Towards morning I attained a dream in which I met you. You looked just as in lifetime and said to me: "That it came to this [my death] is fate. A person's death needs not be lamented. I wish you would not grieve." I was overcome with sorrow and could not hide my tears. Seeing this, you covered your eyes. I wiped away my tears; when I turned to look at you again you were smiling cheerfully. I pulled and dragged [at you?] and unwittingly let off a loud outcry. You then lifted your body and left. I also was called by someone and rose. As if keeping you, as if losing you: your voice still remains in my ears. ${ }^{66}$

All the elements of dream contents which define the "existential dream" are found here as well, especially strikingly the shift of mood. And just as "impactful dreams" in Kuiken and Sikora's definition do, these dreams moved the dreamers to action in waking life: the rituals for which the texts were written seem both to have been conducted on account of having had the dream.

What can we make of these similarities between the dream-life of these historical personages imbued by Confucian values and that of modern Western, supposedly individualistic subjects, concerning our questions about Confucian subjectivity? Do they not bespeak a close proximity in the underlying sense of personhood as well? It might be argued that the ethical construction of self and the psychological processes illustrated by the dream reports lie on very different levels of "self." However, if that is the case, if the self-construction (or rather deconstruction) as ascribed to the Confucian subject by Rosemont et.al. should be assumed to have no impact on inner life processes, what then does it imply or explain at all?

Chemun dream narrations do in many respects confirm the importance of social roles in interpersonal relationships; we have especially seen stability in the role demands on deceased daughters and elder brothers. At the same time, it is obvious from the texts that the beloved dead were not assumed to only consist of their roles but were addressed as individuals who remain beloved and consistent personalities, whether they chose to act according to their roles or not. In other cases, the bond persists while the roles are reversed

66. 向曉得夢。見君顏面如生時。謂余曰。竟爾至此。命也。人之死。不須哭。願 勿感也。余悲不自禁。涕泗交下。君見之輙掩目。余若拭淚回視。則君便歡 笑。余攀掣之間。不覺一長號。而君遂騰身避去。余亦被人呼喚而起。若存若 亡。餘聲未息. Ch'ae Yuhu (1599-1660), “Che Yu Yugang mun (Yŏng).” 
(e.g., a father taking advice from his son who had died at young age $\left.{ }^{67}\right)$. And in instances when the bond slowly slackens, where the gradual dispersal of the soul becomes topical, the social role and its disintegration is never mentioned; it is the soul, the individuality as such, that dissolves and disappears. Even the dead daughter is remembered not only as a dutiful daughter who waited on her parents so well, but as "a human being like you." ${ }^{68}$

What would you have to tell us if you could? This is one of the fundamental questions with which the chemun-many of them-turn to the dead they address. It is also the question with which we as historians turn to our materials, what we would like to know about the authors of our sources. From their dreams and from their conversations about these dreams with their beloved dead, these authors and the subjects of their mourning emerge as vividly speaking persons, full of conflicts and desires, complex yet consistent entities which they themselves believed to outlast even death-as long, at least, as loving memory would keep them alive.

67. Nam Han'gi (1675-1748), "Che manga mun."

68. Sin Tae'u (1735-1809), "Mangyŏ sosang chemun." 


\section{BIBLIOGRAPHY}

\section{Primary sources}

The sources that constitute my sample are marked by a number indicating their chronological sequence at the end of the reference entry. Thus, Yi Chŏnghyŏng's chemun is the earliest, the one by Yi Mansu the latest text in my sample.

CH’AE P'aengyun (蔡彭胤 1669-1731). “Che Och’on Hong Ŭnggyo Ton mun 祭梧村 洪應敎 墪 文.” Hŭiam sŏnsaeng chip 希菴先生集, kw. 26(22).

CH’AE Yuhu (蔡裕後1599-1660). “Che Yu Yugang mun (Yŏng) 祭柳柳巷文 穎.” (for Yu Yŏng 柳穎 1603-1645), Hojujip 湖洲先生集, kw. 5(7).

CH’OE Sŏkchŏng (崔錫鼎 1646-1715). “Che tanghyŏng jinsa mun 祭堂兄進士文.” Myŏnggok chip 明谷集, kw. 10(17).

CHO T'aeŏk (趙泰億1675-1728). “Che manga Ŭibin mun 祭亡兒儀涁文.” Kyŏmjaejip 謙齋集, kw. 35(24).

CHO Wihan 趙緯韓 (1567-1649). “Che mangja Ŭi mun 祭亡子倚文.” Hyŏngok chip 玄谷集, kw. 13.

CHŎNG Hyŏksin (鄭赫臣 1719-1793). “Che Yi Kych’o Puun mun 祭李季初復運文.” Sŏngdangjip 性堂集, kw. 3(30).

IM Chŏk (任適 1685-1728). “Che mangmae yuin Hong-ssi pu mun 祭亡妹孺人洪氏婦 文.” Noŭnjip 老隱集, kw. 3(26).

KANG Paengnyŏn (姜椙年 1603-1681). “Chaja Yi jinsa Sŏngik chemun 姊子李進士 聖翼 祭文.” Sŏlbong yugo 雪峯遺稿, kw. 24(9).

KANG Paengnyŏn (姜栢年 1603-1681). “Mangnyŏ Nam Nangik Hun ch’ 女南郎益熏妻祭文.” Sŏlbong yugo 雪峯遺稿, kw. 24.

KIM Chin'gyu (金鎭圭 1658-1726). “Mangsil chaegi chemun 亡室再期祭文.” Ch'ukch'ŏnjip 竹泉集, kw. 12(19).

KIM Hongyu (金弘郁 1602-1654). “Che Im p'ansŏ Tam mun 祭林判書 墰 文” (for Im Tam 1596-1652), Hakchu sŏnsaeng chŏnjip 鶴洲先生全集 , kw. 9(8).

KIM Sangjŏng (金相定 1722-1788). “Che mangsil mun 祭亡室文.” Sŏktang yugo 石 堂遺稿, kw. 3(31).

KIM Suhang (金壽恒 1629-1689). “Mangnyŏ taesang chŏn iil chemun 亡女大祥前二 日祭文.” Mungok chip 文谷集, kw. 24(14).

KIM Yun'an (金允安 1560-1622). “Che ŭiin Nam puin 祭宜人南夫人.” Tongni sŏnsaeng munjip 東籬先生文集, kw. 4(3).

Ko Yonghu (高用厚 1577-1652). “Che mangsil sukpuin Ki-ssi mun 祭亡室淑夫人奇 氏文.” Ch’ŏngsajip 晴沙集 , kw. 2(5).

KWŎN Si (權諰 1604-1672). “Che Sim-ga cha mun 祭沈家姊文.” T'anong chip 炭翁 集, kw. 12. 


\section{Marion Eggert}

KWŎN Tŏksu (權德秀 1672-1759). “Che mangsil yuin Kim-ssi mun 祭亡室需人金氏 文.”P'ohŏnjip 逋軒集, kw. 4(23).

NAM Han'gi (南漢紀 1675-1748). “Che manga mun 祭亡兒文.” Kiongjip 寄翁集， kw. 4(25).

NAM Yuyong (南有容 1698-1773). “Che woehyŏng Yi-gun Sejin mun 祭外兄李君世 臣文.” Noeyŏnjip 䨓淵集 , kw. 17(29).

O Kwangun (吳光運 1689-1745). “Che Yi chusŏ Wŏnhwan mun 祭李注書元煥文.” Yaksan man'go 藥山漫稿, kw. 17(27).

SIN Tae’u (申大羽 1735-1809). “Mangyŏ sosang chemun 亡女小祥祭文.” Wan'gu yujip 宛丘遺集, kw. 10(33).

SONG Sanggi (宋相琦 1657-1723).“Che manga mun 祭亡兒文”. “Che manga ch’ŏnjang mun. Chŏngyu [1717] 祭亡兒遷葬文 丁酉.” Ogojaejip 玉吾齋集， kw. 16(18).

SoNG Siyŏl (宋時烈 1607-1689). “Che chabu Yi-ssi mun 祭子婦李氏文.” Songja taejŏn 宋子大全, kw. 152(11).

SONG Siyŏl (宋時烈 1607-1689). “Che Ujae Yi-gong mun 祭迂齋李公文” (for Yi Huwŏn 李厚源 1598-1660), Songja taejŏn 宋子大全, kw. 152(10).

Yi Ch“ŏlbo (李吉輔 1691-1770). “Che kyebu mun 祭季父文.” Chiam yugo 止庵遺 稿, ch'aek 3(28).

Yi Chŏnghyŏng (李廷馨 1549-1607). “Che chunghyŏng mun 祭仲兄文,” “Che chungssi ch'ogi mun 祭仲氏初㫷文.” Chit'oedang chip 知退堂集, kw. 4 (for Yi Chŏngam 李廷馣, 1541-1600) (1).

YI Chun (李埈 1560-1634). “Chemun taesang si 祭文 大祥時” (for Chŏng Kyŏngse), in: Chŏng Kyŏngse (鄭經世1563-1633), Ubok sŏnsaeng pyŏlchip 愚伏先生別 集, kw. 12(4).

YI Haejo (李海朝 1660-1711). “Che mangsil sosang mun 祭亡室小祥文.” Myŏngamjip 鳴巌集, kw. 6 (20).

YI Homin (李好閔 1553-1634). “Che Che Sŏae Yu sanggong mun 祭西厓柳相公文.” Obong sŏnsaeng chip 五峯先生集 , kw. 15 (for Yu Sŏngnyong, 1542-1607) (2).

YI Mansu (李晚秀 1752-1820). “Mangja Wŏnu taegi chemun 亡子元愚大㫷祭文.” Kŭkwŏn yugo 屐園遺稿, kw. 9(34).

YI Samhwan (李森煥 1729-1813). “Chae che ihyŏng Ch’ŏnggok-gong mun 再祭二兄 清谿公文.” Somi sanbang chang 少眉山房藏, kw. 3(32).

YI Sang (李翔 1620-1690). “Che Yi ch’amŭi mun 祭李參議文.” T’au sŏnsaeng yugo sok 打愚先生遺稿續 , kw. 2(12).

YI Sisŏn (李時善 1625-1715). “Che chongja chwarang Sŏn mun 祭從子佐郎 瑄 文.” Songwŏljae sŏnsaeng chip 松月斎先生集 , kw. 6(13).

YI Ǔihyŏn (李宜顯 1669-1745). “Che mangja mun 祭亡子文.” Togokchip 陶谷集， kw. 26(21).

YU Chin (柳衫 1582-1635). “Che chunghyŏng sema-gong mun 祭仲兄洗馬公文.” Suam sŏnsaeng munjip 修餀先生文集, kw. 3(6).

YU Semyŏng (柳世鳴 1636-1690). “Che sahyŏng Maedang-gong mun 祭四兄悔堂公 文.” Uhŏn sŏnsaeng munjip 寓軒先生文集 , kw. 7(16). 
YU Sŏngnyong (柳成龍 1542-1607). “Che paekhyŏng mun 祭伯兄文.” Sŏae sŏnsaeng munjip 西厓先生文集, kw. 19.

YUN Chŭng (尹拯 1629-1714). “Che chaejonghje Sŏngyŏ Kyu mun. Kyesa [1713] 祭 再從弟聖汝 揆 文 癸巳.” Myŏngjaesŏnsaeng yugo 明齋先生遺稿, kw. 34(15).

\section{Further References}

AMES Roger (1988). "Rites as Rights: The Confucian Alternative." In RounER Leroy S. (ed.), Human Rights and the World Religions. Notre Dame, University of Notre Dame Press: 199-216.

BARRETT Deirdre (1991-92). "Through a Glass Darkly: Images of the Dead in Dreams." Omega 24(2): 97-108.

CAILlois Roger and Edmund VON GRUNEBAum (eds.) (1966). The Dream and Human Societies. Berkeley, California University Press.

DE Groot Jan J. M. (1892). The Religious System of China, vol. III, Book 1. Leyden, Brill.

DEUCHLER Martina (2015). Under the Ancestors' Eyes. Kinship, Status and Locality in Premodern Korea. Cambridge (MA), Harvard East Asia Center.

EDWARDS E.D. (1948). "A Classified Guide to the 13 Classes of Chinese Prose." Bulletin of the School of Oriental and Asian Studies 12(3-4): 770-788.

EGGERT Marion (1993). Rede vom Traum. Traumauffassungen der Literatenschicht im späten kaiserlichen China. Stuttgart, Steiner.

EGGERT Marion (1995). “Traditional Korean Ideas on Dreams.” In KoREA FoundATION (ed.), A Collection of Theses on Korean Studies. Seoul: 191-214.

EGGERT Marion (2018). "Beyond Prognostication. Future in Sinic Dream Explications." In DIETERLE Bernard and Manfred ENGEL (eds.), Theorizing the Dream/Savoir et théories du rêve. Würzburg, Königshausen \& Neumann: 59-75.

GRAYSON James H. (2007). "The Grievance Rite: A Protestant Response to Confucian Ancestral Rites." In Buswell Robert E. (ed.), Religions of Korea in Practice. Princeton, Princeton University Press : 434-445.

HeJtMAnEK Milan (2014). "The Familiar Dead. The Creation of an Intimate Afterlife in Early Chosŏn Korea.” In HoRlyck Charlotte and Michael PeTtID (eds.), Death, Mourning and the Afterlife in Korea. From Ancient to Contemporary Times. Honolulu, University of Hawai'i Press: 155-167.

Hollan Douglas (1995). "To the Afterworld and Back: Mourning and Dreams of the Dead among the Toraja." Ethos, 23(4): 424-436.

HunTINGTON Rania (2017). "Rêves des morts: cas tirés des annales de la famille Yu de Deqing." In LAUREILLARD Marie and Vincent DURAND-DASTÈs (eds.), Fantômes dans l'Extrême-Orient d'hier et d'aujourd'hui, tome 1. Paris, Presses de l'Inalco: 171-201.

KUIKEN Don and Shelley SIKORA (1993). "The Impact of Dreams on Waking Thoughts and Feelings." In MofFitT Allan, Kramer Milton et Robert HofFMAN (eds.), Functions of Dreaming. Albany, State University of New York Press: 419-475. 


\section{Marion Eggert}

LEVInE David P. (2011). The Capacity for Civic Engagement. Public and Private Worlds of the Self. New York, Palgrave Macmillan.

PETTID Michael (2014). "Ghostly Encounters: Perceptions of Death and the Afterlife in Koryŏ and Early Chosŏn." In HoRLYCK Charlotte and Michael PETTID (eds.), Death, Mourning and the Afterlife in Korea. From Ancient to Contemporary Times. Honolulu, University of Hawai'i Press: 171-189.

ROETZ Heiner (1993). Confucian Ethics of the Axial Age. New York: SUNY Press.

Rosemont Henry and Roger AMES (2016). Confucian Role Ethics. A Moral Vision for the 21st Century?. Göttingen, Vandenhoeck \& Rupprecht.

Shulman David and Guy Stroumsa (eds.) (1999). Dream Cultures: Explorations in the Comparative History of Dreaming. Oxford, Oxford University Press.

WAGNER Rudolf (1988). "Imperial Dreams in China.” In BROWN Carolyn T. (ed.), Psycho-Sinology. The Universe of Dreams in Chinese Culture. A Conference Report. Lanham, Woodrow Wilson Center : 11-24.

YI Wŏryŏng (2011). Kkum-kwa kojŏn munhak [Dream and Premodern Literature]. Seoul, T'aehaksa. 
Dreaming about the Dead in Premodern Korea (17th-19th Century)

\title{
GLOSSARY
}

\author{
changgyŏng myŏnghwi 長景明暉 \\ chemun, chin. jiwen 祭文 \\ chŏnghon 精魂 \\ chŏngryŏng 精靈 \\ chŏngsin 精神 \\ ch'ungmun 祝文 \\ hon 魂 \\ hyŏn 現 \\ kwŏn 券 \\ kyŏn 見 \\ Lan Caihe 藍采和 \\ lei (“eulogy”) 昩 \\ Min Usu 閔遇洙 \\ mong $a$ 夢我 \\ mong 夢 \\ munjip 文集 \\ munjip ch'onggan 文集總刊 \\ pae 拜 \\ paek 魄 \\ Sang and in 想因 \\ Shijing 詩經 \\ sinjŏng 神精 \\ Tage 踏歌 \\ Yi Huwŏn 李厚源 \\ Yi Hwang (T’oegye) 退溪李滉 \\ Yi I (Yulgok) 栗谷 李珥 \\ yŏng 靈 \\ Yu Tan 柳袻
}


